\title{
Student's greetings from TEFI10 conference in Pyhä
}

Pia-Maria Hokkanen, University of Lapland, Multidimentional Tourism Institute (MTI)

When I returned home from the conference to my shared student apartment in Rovaniemi and sat down on my floor mattress, I was feeling lucky, exhausted, inspired, and more lost and awakened at the same time. For me, those couple of days under Pyhä fell had been more than an ordinary conference experience. The conference had gotten under my skin - emotionally, physically, socially, and cognitively.

I was a third-year master's degree student in tourism research, and I was pondering the path on which I should continue: would it be under the structures of academia as a researcher, or perhaps a trendy entrepreneurship dream (or nightmare)? Maybe I would enjoy being a normal worker in someone's company. Or what if I end up in an entirely different field? Participation in TEFI's conference "Knowing with nature - the future of tourism in the Anthropocene" made me seriously reconsider all my thoughts about the future.

I realized the Anthropocene is an epoch that must be considered with care. Originating from the natural sciences, the term refers to humanity's power to geologically move, shift, and impact the planet (Gren \& Huijbens, 2014, p. 1). I understood that it can bring a huge load of responsibility, and can almost result in a mental paralysis in a person. I was not encountering this issue for the first time in the conference, but recognition of the significant influence of human action had hit me like a punch in the face during my studies and work.

When I started my studies in tourism in 2012, I totally believed in turquoise waters, happy fish, rich coral reefs, shiny holiday moods, and tourism as a gateway to develop community and hospitality behind every door. Today, waters are darker and deeper, coral reefs are grey, and fish swallow plastic. There exist communities that hate tourism because of its impacts. In response to these notions, I had tried to find a holiday in a family forest rather than dreaming of my next holiday trip in Southeast Asia. I suppose nature had shaken me in a way that left my anger and sadness towards the field of tourism elevated: is this exploitation? I do not want to be part of this.

These darker thoughts propagated during a dream job as a tourist guide in a company with a good reputation in 2016 . Fringe benefits, such as living in warm places, the ability to travel for work, after-work drinks at the beach, and swimming pools suffice to stifle my misgiving about 
tourism industry for some time, but soon I came to a point where I realized that this was not right. I found myself cleaning the plastic from the sea during my days off, guiding drunken tourists older than myself to their destinations, and getting myself caught in the middle of political warfare. I could not understand what was happening around me. I thought I needed more tools to understand all of this. I desperately wanted someone to tell me how to deal with all this, so I hiked to the University of Lapland and left behind the fresh fruits of the Mediterranean climate.

\section{Staying with the trouble}

The conference provided significant ways to deal with the pain of being a human. One of the most powerful insights came from the Icelandic professor Gunnar Thór Jóhannesson. His words comforted me in my anxious existential crisis: 'Stay with the trouble.' 'Staying with the trouble' refers to Donna Haraway's idea of engaging with the present, with all its troublesomeness (Haraway 2016, p. 1). During Gunnar's keynote speech on the very first day, I was sitting on the ground in the cold, pouring rain in a not-so-waterproof outfit. I stayed - I wanted to take that sentence to heart. Maybe it was Icelandic charm, Jóhannesson's calm presence in harsh conditions, or my weak, light-hearted mindset, but in that moment, the rain and its humble invitation to stay sounded like a symphony that should have been played nonstop in my heart.

Still feeling the cold summer rain of Lapland on my skin, I continued practicing Haraway's thought. I found myself in the middle of the trouble at the table with professors, teachers, and researchers. I felt lonely and separated, it was hard to place myself with these people. My troubled mind spoke to me: I am just a student. How should I talk to these people? Are they even interested in my thoughts? During those moments of loneliness, I was missing my creatures other students with whom I could have shared my feelings. I did not have that chance, and I had to stay with the trouble and move along with it. To be honest, I am happy I stayed.

\section{Dwelling with the trouble}

Not only staying, but also dwelling with the trouble, forced me to dive deeper into accepting what is. I shared a beautiful cottage with teachers and professors, and post-seminar discussions in the sauna revealed to me a new side of family and caring in an academic context, which I understood is not separate from academic life, but connected and intertwined. My troubled mind wanted to float in this beautiful place of belonging and understanding, but I was reminded of the hierarchies between student and teacher. I felt uncomfortable dwelling together. Miia Mäkinen, Outi Rantala, and Kaarina Tervo-Kankare's presentation made me understand more about my struggle, and their talk of friendship of a place resonated in me. I acknowledged how friendship demands time, and wondered whether only a few conference days together with people and place might not be enough for strong bonding (see Mäkinen, Rantala, \& Tervo-Kankare 2016, pp. 26-41).

TEFI community (tourismeducationfutures.org) had emphasized equality and openness in their practices. They had taken a step towards disrupting hierarchies by inviting students into the dwelling, and to invite children in the conference (a decision which made me especially hap- 
py). When I looked at children with their families at the conference, I realized that these people were not only researchers, but also mothers and fathers. It is not all about studying. Life happens at the same time! Professors do normal things as well! I started to develop a more diverse perspective on academic life, because studying under the structures of the university had not revealed to me this side of academic life before.

I had my hardships in dwelling with the trouble, but I got a chance to practice understanding and compassion through various activities. Meditation in the forest and poetic sessions improved friendship with the place and undressed everyone as professors, researchers and students: we were all together in the same position, with Mother Earth and with the art of words. I saw how academic diversity and co-operation during our multidisciplinary sessions bloomed together - literature, arts, geology, architecture, anthropology, archaeology, all came together under tourism discourse.

Usage of language in Christer Foghagen's and Emily Höckert's (2018) poetic session made me wonder about the ways of expression in academic writing and boundaries in language. Jonathan Karkut and Julie Scott (2018) talked about reconnecting with a rock, synching human time with Earth time, and made me wonder in awe: how should we follow a rock's time? Maybe we could try Stone Walks (Springgay \& Truman, 2017, p. 851) in our next conference? We had already sat with the rain as if the rain had been one of the conference's guests - and then, we could walk with stones.

As Springgay and Truman (2017, p. 858) disclose, Stone Walks call for the reconsideration of the taxonomies of rocks, and encourage us to rethink effects as not human only, but to expand our thinking to inhuman entities - to think of such effects as friction, flow, trajectory, tendency, and liveliness, and extend the thought from human-centrism towards a material world that is not only an external place, but the substance of ourselves and others. When I think about these queer feelings of Stone Walks, I think it would have some serious consequences to our beingin-the-world. Perhaps we could learn with the world, rather than about it (Springgay \& Truman ,2017, p. 858).

Brendan Paddison's (2018) presentation expanded the time horizon with a different perspective. Paddison led us to the past by introducing a project where a community participated in archaeological research in order to engage with their heritage. Paddison's team had found out that participation in excavations can increase wellbeing in the community, as well as contribute to value creation, sense of place, and cultural and social identities. I had observed that in the excitement of the future and "development," we tend to forget what happened, how we are, and how we were. Exploring roots can be a touching, moving, and life-changing experience.

\section{Final thoughts}

Being back in the student life, I am more aware that tourism education is tied to the Anthropocene, and learning with, not only about it, is essential. Participation in this conference comforted me through the pain of staying with the trouble, and I am thankful for those who inspired me, and especially for those who have troubled me. I believe practices of patience are a more 
sustainable form of recovery. I hope that in future TEFI conferences, there will be chances for more students to get involved and to reflect their learning through these thought-provoking, troublesome events.

\section{References}

Foghagen, C., \& Höckert, E. (2018). Sympoetics in the Anthropocene. In O. Kugapi \& M. Äijälä (Eds.), Knowing with nature - The future of tourism education in the Anthropocene. Conference proceedings (p. 10). Rovaniemi: Multidimensional Tourism Institute.

Gren, M. , \& Hujbens, E. (2014). Tourism and the Anthropocene. Scandinavian Journal of Hospitality and Tourism, 14, 6-22. https://doi.org/10.1080/15022250.2014.886100

Haraway, D. J. (2016). Staying with the trouble: Making kin in the Chthulucene. Durham and London: Duke University Press.

Karkut, J., \& Scott, J. (2018). Reconnecting with rock: Dismantling dichotomies in and Anthropocene geopark. In O. Kugapi \& M. Äijälä (Eds.), Knowing with nature-The future of tourism education in the Anthropocene. Conference proceedings (p. 49). Rovaniemi: Multidimensional Tourism Institute.

Mäkinen, M., Rantala, O., \& Tervo-Kankare, K. (2018). Väylänvarrella - Tieteidenvälisen dialogin soveltamisesta luontomatkailukohteiden suunnitteluun. Matkailututkimus, 14(1), 26-41.

Paddison, B. (2018). Digging up the past to understand your present: Community engagement in heritage and archaeology, In O. Kugapi \& M. Äijälä (Eds.), Knowing with nature - The future of tourism education in the Anthropocene. Conference proceedings (p. 47). Rovaniemi: Multidimensional Tourism Institute.

Springgay, S., \& Truman, S. E. (2017). Stone Walks: Inhuman animacies and queer archives of feeling. Discourse: Studies in the Cultural Politics of Education, 38, 851-863. https://doi.org/10.1080/ 01596306.2016 .1226777 